\title{
Geleneksel ve Yenilikçi Paketleme Teknolojileri: Balıketi Muhafazasında Potansiyel Kullanımı
}

\author{
Nazan KUTLU1(i), Zafer CEYLAN ${ }^{2}$ (D), Mehmet Mustafa EKİN ${ }^{3(i)}$ ve \\ Raciye MERAL 4
}

How to cite: Kutlu, N., Ceylan, Z., Ekin, M. M., \& Meral, R. (2021). Geleneksel ve yenilikçi paketleme teknolojileri: Balıketi muhafazasında potansiyel kullanımı. Sinop Üniversitesi Fen Bilimleri Dergisi, 6(1), 7894. https://doi.org/10.33484/sinopfbd.754521

Derleme

\author{
Sorumlu Yazar \\ Nazan KUTLU \\ n.kutlu@yahoo.com
}

\section{Yazarlara ait ORCID}

N.K.: 0000-0002-2225-6600

Z.C.: 0000-0002-6527-4382

M.M.E: 0000-0002-4239-0735

R.M: 0000-0001-9893-7325

Received: 18.06 .2020

Accepted: 05.02.2021

\section{$\ddot{O} \mathbf{z}$}

Gıdaların üreticiden tüketiciye ulaştırılması sürecinde ürünün tazeliğinin ve besin değerinin korunması oldukça önemlidir. Bu amaçla geçmişten günümüze kadar çeşitli muhafaza yöntemleri kullanılmaktadır. Paketleme teknolojisi de bu muhafaza yöntemlerinden biri olup ürünlerin raf ömrünün güvenli bir şekilde artırılması amaçlanmaktadır. Geleneksel paketleme yöntemleri (adi paketleme, vakum paketleme, modifiye atmosfer paketleme, sous-vide paketleme) sadece ürünü korumayı hedef almaktaydı. Gelişen teknoloji ile birlikte tüketiciyi bilgilendirme, ambalaja fonksiyonel özellik kazandırma, çevreye daha az zarar veren ambalaj materyali geliştirme gibi konuların da önem kazandığı yenilikçi paketleme yöntemleri (akıllı paketleme teknolojisi ve nanoteknoloji tabanlı paketleme teknolojisi) geliştirilmiştir. Balıketi çoklu doymamış yağ asidi bakımından zengin olduğundan lipid oksidasyonu balığın duyusal ve besinsel kalitesini olumsuz yönde etkilemektedir. Ayrıca mikrobiyal bozulmalar da su ürünlerinin besinsel değerini düşürmektedir. $\mathrm{Bu}$ olumsuz etkilerin en aza indirilmesi ve bozulmanın geciktirilmesi amacıyla su ürünlerinin muhafazasında geleneksel ve yenilikçi paketleme yöntemleri tek başına veya başka bir paketleme yöntemi ile birlikte kullanılmaktadır. $\mathrm{Bu}$ derlemede geleneksel ve yenilikçi paketleme yöntemleri ve bunlarla ilgili uygulamalar hakkında bilgi verilmesi amaçlanmıştır.

Anahtar kelimeler: Balıketi muhafazası, raf ömrü, geleneksel paketleme yöntemleri, yenilikçi paketleme yöntemleri

\section{Traditional and Innovative Packaging Technologies: Potential Use in Fish Meat}

\section{Storage}

${ }^{1}$ Van Yüzüncü Y1l Üniversitesi, Fen Bilimleri Enstitüsü, Gıda

Mühendisliği ABD, Van, Türkiye

${ }^{2}$ Van Yüzüncü Y1l Üniversitesi, Turizm Fakültesi, Gastronomi ve Mutfak Sanatları Bölümü, Van, Türkiye

${ }^{3}$ Van Yüzüncü Yıl Üniversitesi, Özalp Meslek Yüksekokulu, Gıda

\begin{abstract}
It is very important to preserve the freshness and nutritional value of the product during the delivery of food from the producer to the consumer.For this purpose, various preservation methods have been used from past to present.Packaging technologyis one of these preservation methods by which it is aimed to increase the shelf life of products safely.Traditional packaging methods (plain packaging, vacuum packaging, modified atmosphere packaging, sous-vide packaging) only aim to protect the product.With the developing technology, innovative packaging methods (smart packaging technology and nanotechnology-based packaging technology) have been developed, where issues such as informing the consumer, providing functional properties to the packaging, developing
\end{abstract}




\begin{tabular}{cl}
\hline $\begin{array}{c}\text { Teknolojisi Programı, Van, } \\
\text { Türkiye }\end{array}$ & $\begin{array}{l}\text { packaging materials that are less harmful to the environment are also } \\
\text { important.Since fish is rich in polyunsaturated fatty acids, lipid oxidation } \\
\text { negatively affects the sensory and nutritional quality of fish.In addition, } \\
\text { microbial spoilage also reduces the nutritional value of seafood.In order } \\
\text { to minimize these adverse effects and delay spoilage, traditional and }\end{array}$ \\
$\begin{array}{c}\text { Man Yüzüncü Y1l Üniversitesi, } \\
\text { Mühendislik Fakültesi, Gida } \\
\text { Mühendisliği ABD, Van, Türkiye } \\
\text { innovative packaging methods are used alone or in combination with } \\
\text { another packaging method for the preservation of seafood.In this review, } \\
\text { it is aimed to give information about traditional and innovative packaging } \\
\text { methods and their applications. }\end{array}$ \\
$\begin{array}{c}\text { Bu çalışma Creative Commons } \\
\text { Attribution 4.0 International } \\
\text { License ile lisanslanmıştır }\end{array}$ & $\begin{array}{l}\text { Keywords: Fish meat storage, shelf life, traditional packaging methods, } \\
\text { innovative packaging methods }\end{array}$ \\
\hline
\end{tabular}

\section{Giriş}

Son yıllarda, ülkelerin gelişme düzeyinin artış1 insanları sağlıklı beslenmeye ve buna bağlı olarak daha özenli gıda seçimine yönlendirmiştir. Bu gidalar içerisinde balık ve diğer su ürünleri öne çıkmaktadır. Bunun en önemli nedenleri; su ürünlerin yüksek oranda çoklu doymamış yă̆ asidi içermesi, et kalitelerinin ve besin değerlerinin yüksek olması şeklinde sıralanabilir. Fakat balıketi; uygun olmayan proses ve depolama koşullarında, kimyasal bileşimi nedeniyle hızlı bozulma göstermektedir [1, 2].

Ülkemizde kı1 bölgelerinde avlanma yapıldığından, balıkların büyük bir kısmı avlandığı bölgede taze tüketilmektedir. Su ürünlerinin; avlanma bölgesinin dışındaki bölgelere ulaştırılmasında kalitelerinin korunması sağlanmalıdır. Bunu gerçekleştirmek için çeşitli muhafaza yöntemlerinin uygulanması gerekmektedir [3].

Bir ürünün raf ömrünü ele aldığımızda; ürünün işlenme sırasındaki tüm basamakları göz önünde bulundurmak gerekmektedir. Paketleme işlemi de bunlardan biridir. $\mathrm{Bu}$ durumda ürünün işlenmesi sırasında paketleme yönteminin seçimi oldukça önemli bir husustur.
Ürünün raf ömrü belirlenirken ilk olarak mikrobiyolojik güvenlik kontrolü yapılmalı ve bununla birlikte kimyasal ve duyusal kalite özellikleri birlikte değerlendirilmelidir. Birçok g1da ürününde, proses aşamasında ürünün önceden bilinen özellikleri raf ömrünün belirlenmesinde yol gösterici niteliktedir. $\mathrm{Bu}$ özellikler; ürünün besinsel bileşimi gibi iç faktörler, çevreden kaynaklı dış faktörler ve bu ikisinin birlikte oluşturduğu kombinasyon olarak belirtilebilir. Bunlar raf ömrünü kısıtlayıcı faktörlerdir. Paketlenmiş ürünler, dış faktörlerden önemli ölçüde etkilenirler. Uygulanan paketleme yöntemi ile birden fazla faktörün kontrol altına alınmasıyla (1şı ve havanın tamamen engellenmesi gibi), bu işlem tek başına raf ömrünü uzatabilir, aksi halde yeterli olmayabilir. Bazı durumlarda iç ve dış faktörler arasında; kimyasal/biyokimyasal, mikrobiyolojik ve fiziksel reaksiyonların oluşumu raf ömrünü sınırlandırır. Bazı durumlarda ise bu etkileşimler, üründe istenilen özelliklerin oluşmasını da sağlayabilmektedir [4].

İnsanlar hem sağlık hem de görünüm açısından açık halde satışa sunulan gıdalardan ziyade paketlenmiş gıdaları tercih etmektedirler. Yaşadığımız çevrede insan sayısının artması 
sonucu gida kaynaklarında yetersizlikler kendini göstermeye başlamıştır. $\mathrm{Bu}$ yetersizlikler farklı gidalara olan ihtiyacı oluşturmaktadır. Gıdalarda çeşitliliğin artması, sadece hammadde açısından değil ambalaj materyali açısından da önemli hale gelmiştir [5].

Dünya nüfusunun hızla artması ve gelişen teknolojiler su ürünlerinin çeşitli yöntemlerle tüketiciye sunulmasını gerektirmektedir. $\mathrm{Bu}$ anlamda günümüze kadar çok sayıda paketleme teknolojisi geliştirilmiş ve bu teknolojiler ile balıketinin daha uzun süre ve güvenli bir şekilde saklanması hedeflenmiştir. Uzun yıllardır kullanılan geleneksel paketleme yöntemlerine ilaveten, akı1lı ambalajlar, yenilebilir filmler ve nanoboyuttaki liflerle ve/veya partiküller içeren ambalaj kullanılarak yapılan ambalajlamalar da balıketinin muhafazasında önem kazanmaya başlamıştır. $\mathrm{Bu}$ çalışmada, balıketi muhafazasında kullanılan geleneksel ve yenilikçi paketleme yöntemleri hakkında bilgi verilmiştir.

\section{Geleneksel Paketleme Teknolojileri}

\section{Adi Paketleme}

Elle veya basit makinelerle, besin maddesinin çevresinin bir paketleme maddesi ile sarılması işlemidir. Besin maddeleri paketlenecek miktarda tartılıp ayrılarak paketleme maddesinin içine konulur ve ağzı kapatılır. Paketlemeden istenilen sonucun alınmas1 paketleme maddesinin cinsine ve paket içinde kalan hava miktarına bağlıdır [5]. Adi paketleme, hızlı uygulanan ve oldukça düşük maliyetli bir yöntemdir. Fakat üründe oksidasyona bağlı renk değişiminin kısa sürede gerçekleşmesi, mikrobiyal açıdan bozulma, nem ve $\mathrm{pH}$ 'da istenmeyen değişimlerin en hızlı şekilde meydana gelmesi gibi dezavantajları bulunmaktadır [6].

\section{Vakum Paketleme (VP)}

VP yöntemi, düşük maliyetli olduğundan s1klıkla kullanılan alternatif bir paketleme yöntemidir. Özellikle yağlı balıkların paketlenmesinde avantaj sağlamaktadır. Çünkü yağlı balıklar $\mathrm{O}_{2} \quad$ varlığında kolayca otooksidasyona uğrayabilmektedir. VP yöntemi ile ortamda bulunan $\mathrm{O}_{2}$ 'nin minimum düzeyde tutulması balığın kalitesini korumakta (özellikle balıketi renginin uzun süre muhafazası) ve raf ömrünü arttırmaktadır [7-10].

VP, gaz geçirimsiz veya amaca göre belirli düzeyde gaz geçirgenliğine sahip bir ambalaj içerisindeki havanın vakum yoluyla uzaklaştırılması ve yerine herhangi bir gaz doldurulmadan paketin kapatılması işlemini kapsayan bir tür pasif MAP yöntemidir.

VP yönteminde paket içerisinde az da olsa $\mathrm{O}_{2}$ kalabilir. Fakat pakette kalan $\mathrm{O}_{2}$ kısa sürede aerobik mikroorganizmalarca kullanılır ve $\mathrm{CO}_{2}$ üretilir. $\mathrm{Bu}$ tip ürünlerde, paket içerisinde $\mathrm{O}_{2}$ bulunmadığından mikroorganizmaların gelişimi ve ürünlerin oksidasyona bağlı bozulması önlenmiş olunur $[9,11]$.

Ambalaj içerisinde $\mathrm{O}_{2}$ miktarının $\% 0.1$ 'den düşük bir seviyeye indirilmesi iyi bir VP gerçekleştirildiğinin göstergesidir. Ancak VP'de anaerobik mikroorganizma riski bulunmaktadır. VP yöntemi soğutma veya 
dondurma yöntemleri ile kombine edilirse bu riski ortadan kaldırmak mümkün olabilir [12].

\section{Modifiye Atmosfer Paketleme (MAP)}

MAP, paket içerisindeki havanın uzaklaştırılıp bunun yerine bir veya birden fazla gazın eklenmesi prensibine dayanan bir paketleme yöntemidir. MAP yöntemi için iz gaz olarak, karbonmonoksit (CO), nitrözoksit $\left(\mathrm{N}_{2} \mathrm{O}\right)$, nitrik oksit (NO), sülfür dioksit $\left(\mathrm{SO}_{2}\right)$, etan $\left(\mathrm{C}_{2} \mathrm{H}_{6}\right)$ ve klor (Cl) gibi gazların kullanılması önerilse de maliyet açısından çoğunlukla karbondioksit $\left(\mathrm{CO}_{2}\right)$, oksijen $\left(\mathrm{O}_{2}\right)$ ve nitrojen $\left(\mathrm{N}_{2}\right)$ gazlarının kullanımı tercih edilmektedir. $\mathrm{Bu}$ gazların kullanılmamasının başlıca nedenleri: güvenlik sorunu, tüketicinin üründe istememesi, yasal kullanım miktarları şeklinde sıralanabilir. $\mathrm{CO}_{2}$ gazı bakteri ve mantarların gelişimini engelleyici etkiye sahip olduğundan; su ürünlerinde MAP uygulamasinda kullanılan en önemli gazdır. $\mathrm{Bu}$ engelleme paket içerisinde bulunan $\mathrm{CO}_{2}$ konsantrasyonun yükseltilmesine bağlı olarak artış göstermektedir. Fakat paket atmosferinde çok fazla $\mathrm{CO}_{2}$ konsantrasyonu, balık derisinin gaza maruz kalan yüzeyinin beyazlamasına, balıketinde aşırı su kaybının oluşmasına ve balıkta duyusal yönden köpüğümsü bir tadın meydana gelmesine neden olmaktadır. $\mathrm{N}_{2}$ gazının MAP yönteminde kullanımın en önemli nedenleri; basıncı giderici bir doldurucu (filler) gaz olması ve ürünün ezilme ve/veya yapışma problemlerini ortadan kaldırarak paket bütünlüğü sağlamasıdır. $\mathrm{O}_{2}$ gazı su ürünlerinin rengini korumakta, beyaz etli ürünlerde su kaybını azaltmaktadır; fakat yağlı balıklarda oksidasyonu artırıcı etkisinden dolayı kullanımı tercih edilmemektedir [10].

1920-1930’lu yıllarda MAP yönteminin kullanımı üzerine; meyve, sebze, su ürünleri ve kırmızı ette raf ömrünü arttırmayı amaçlayan temel çalışmalar yapılmıştır [13].

MAP, yüksek kalitede ürün sağlamanın yanı sıra, raf ömrünü arttırmak suretiyle ekonomik kayıpları azaltması, ürünlerin daha uzun mesafelere dağıtılmalarına olanak sağlaması ve dağıtım masraflarını azaltması, daha az kimyasal ajan kullanımını desteklemesi, dilimlenmiş ürünlerin ayırımını kolaylaştırması, kokusuz ve kullanışlı ambalajlamaya izin vermesi gibi birçok avantaja sahiptir. Bununla beraber ek maliyet ve sıcaklık kontrolü gerektirmesi, her ürün için farklı gaz kompozisyonlarının oluşturulması, taşıma esnasında paketlerde meydana gelebilecek yırtılma delinme gibi fiziksel zararların gaz kompozisyonunu değiştirmesi dolayısıyla ürün güvenliğinin bozulması gibi dezavantajları da bulunmaktadır [14].

MAP yöntemi ile gıdalarının muhafazasında dört farklı yöntem uygulanmaktadır. Bunlar;

- VP,

- Paket içerisine belirli gaz karışımının doldurulması (aktif yöntem),

- Pasif yöntem ve

- Atmosfer modifiye edicilerin kullanılmasıdır [9].

Pasif yöntem ile MAP uygulamasında, gıda ürünü uygun bir materyal ile paketlenmekte ve sonrasında paket içinde yer alan gazlar ürünün solunumu ile kendiliğinden bir dengeye 
ulaşmaktadır. Buna bağlı olarak; pasif yöntemin aktif yönteme göre daha yavaş bir paketleme yöntemidir. Fakat maliyeti daha düşük olduğundan özellikle son yıllarda, hızlı bozulma gösteren meyve ve sebzelerin paketlenmesinde geçirgen materyal kullanımıyla uygulanmaktadır [8].

Atmosfer modifiye (absorbe) edicilerin kullanılması, VP gıda ürününün kalitesini koruduğu ve raf ömrünü uzattı̆g halde, bu yöntem uygulanarak paketlenen ürünlerde pakette kalan az miktarda $\mathrm{O}_{2}$ 'e bağlı olarak hala aerobik bozulma meydana gelebilir. Yapılan çalışmalarda aerobik mikroorganizmaların \%12 düzeyinde $\mathrm{O}_{2}$ bulunan ortamda gelişebildikleri tespit edilmiştir. Bununla birlikte, bu mikroorganizmalar $\mathrm{CO}_{2}$ seviyesinin yükseltildiği ortamlarda da gelişebilmektedir. VP yöntemi uygulanan gıda ürünlerinde aerobik mikroorganizmaların gelişimini tamamen inhibe edebilmek için ek kontrol metotları gereklidir. Ek kontrol metotlarından biri olan $\mathrm{O}_{2}$ absorbe edicilerin kullanımı Japonya'da geliştirilmiştir. Bu yöntemde atmosfer modifiye ediciler paket içerisine yerleştirilir. Ambalaja yerleştirilen bu atmosfer modifiye ediciler, paket içerisindeki atmosferde bulunan $\mathrm{O}_{2}$ 'i veya etileni absorbe ederek, $\mathrm{CO}_{2}$ ya da etanol üretir ve böylece arzu edilen gaz kompozisyonunun oluşmasını sağlar [8, 13].

\section{Sous-Vide Paketleme (SV)}

SV paketleme yöntemi, sıcaklığın kontrol edildiği koşullarda, gıdaların vakumlu ambalajlarda pişirilmesi işlemidir. Bu yöntemle gıda ürünü katkısız ya da sos-baharat gibi katkılarla birlikte vakum ambalaj içerisinde pişirilir [15]. SV teknolojisinde gıda ürünü, 1sıya dayanıklı plastik paketlere konulur ve vakumlama işlemi yapıldıktan sonra paket kapatılır. Vakumlanmış paket, sıcaklığın kontrol edildiği ve içinde su dolaşımının olduğu pişirme kabına konularak uygun sıcaklık-süre parametresine göre pişirilir. Pişirme işleminden sonra ürün su dolu kaptan çıkartılarak doğrudan, 1zgara veya tavada kızartma işlemi uygulanarak servis edilir. SV yöntemi uygulanan ürünlerin tüketimi iki şekilde olabilmektedir. $\mathrm{Bu}$ işlemlerden biri; vakum ambalajlama, pastörize etme, tüketim için hazırlama ve servis etme aşamalarından oluşan pişirme-servis (cookserve/hold)'dir. Diğer tüketim şekli ise; vakum ambalajlama, pastörize etme, hızlı soğutma, soğukta depolama, tüketim öncesi 1sıtma, tüketim için hazırlama ve servis etme aşamalarından oluşan pişirme-soğutma (cook-chill/freeze)'dır [16].

SV paketleme yönteminde, geleneksel pişirme işleminde kullanılan sıcaklıktan daha düşük sicaklıklar (genellikle $100^{\circ} \mathrm{C}$ 'nin altında) ve daha uzun pişirme süreleri kullanılır. En düşük sıcaklıklar balık ve et pişirmek için kullanılırken (örneğin $\quad 70^{\circ} \mathrm{C}$ 'nin altında), sebzeleri pişirmek için daha yüksek sıcaklıklar kullanılmaktadır (örneğin $95^{\circ} \mathrm{C}$ ). Hassas ürünler veya sıcak sos içeren ürünler tam olarak vakumlanamaz. Bu durumun bir sonucu olarak; ambalajda kalan hava miktarı, ambalajın içindeki ürün çeşidine bağlı olarak farklılık göstermektedir [15]. 
SV teknolojisi ile su ürünlerinin doymamış yağ asidi ve vitamin değerleri korunmaktadır. Patojen bakteriler su ürünlerinin bozulmasına neden olmakta ve ürünün hem sağlık hem de finansal açıdan kalitesini etkilemektedir. $\mathrm{Bu}$ nedenle ürüne uygulanacak ișleme karar verilirken patojen bakterilerin etkilerinin ortadan kaldırılması hususuna da dikkat edilmelidir. Düşük sıcaklıklarda pastörizasyon işlemi gıdaları güvenli hale getirebilmektedir. SV teknolojisinde sabit 1s1 uygulamas1 ile su ürünlerinin, tat ve besin değerlerinin korunarak raf ömrünün uzatıldığı yapılan çalışmalarda görülmektedir. SV paketleme yöntemi uygulanan su ürünlerinin raf ömrü; geleneksel yöntemlerden olan firında pişirme, buharda pişirme ve bunun gibi işlemlere tabii tutulan ürünlerin raf ömründen daha uzundur. Bununla birlikte SV paketleme yöntemi ile pişirilen su ürünleri diğer geleneksel pişirme yöntemleri uygulanan ürünlere göre; daha iyi mikrobiyolojik, kimyasal, besinsel ve duyusal kaliteye sahip olmaktadır [17].

SV paketlemenin uygulanan işlem basamakları pratik olduğundan bu yöntemin kısa sürdüğünü ve fazla iş gücü gerektirmediğini söyleyebiliriz. $\mathrm{Bu}$ yöntem tüketici açısından servise hazır ürün sunmayı sağlamaktadır. SV ile ambalaj içindeki $\mathrm{O}_{2}$ miktarı düşürüldügünden bakteri faaliyetleri önlenmiş olmaktadır. Bu yöntem ile ürünler; baharat, yağ ve farklı soslar ile çeşitlendirilebilir. SV paketleme yönteminin bu avantajlarının yanı sıra bazı dezavantajları da mevcuttur. SV
ISSN: 2536-4383

yöntemindeki işlem basamakları alet ve ekipman kullanımı gerektirdiğinden işletme maliyetini arttırıc1 bir uygulamadır. SV uygulaması yapılan ürünlerde sık1 bir soğuk zincir takibi yapılmalıdır. Uygulanacak sıcaklık ve sürenin yetersiz olması $C$. botulinum'un toksik etki oluşturmasına neden olabilmektedir [18].

$\mathrm{Bu}$ dezavantajlara ilaveten SV teknolojisinde, ürünün konulduğu paket materyalinin yapımında kullanılan bileşenlerinin ısıl işlem sırasında ürüne geçebileceği görüşü tartış1lan bir konudur. Bu durum sadece SV paketleme yöntemi uygulanan ürünler için değil, yüksek sıcaklıkta uzun süre işlem gören balıklarda kansere neden olan benzopyren bileşiğinin ortaya çıkmasına neden olabilmektedir [17]. 
Tablo 1. Geleneksel paketleme teknolojileri ile ilgili yapılan bazı çalışmalar

\begin{tabular}{|c|c|c|}
\hline Paketleme Metodu & Uygulanan Su Ürünü & Literatür \\
\hline Adi Paketleme & Kahverengi alabalık (Salmo trutta macrostigma) & [6] \\
\hline VP & Sardalya (Sardina pilchardus) & [19] \\
\hline VP & Tirsi (Alosa immaculata) & [20] \\
\hline MAP & Gökkuşağı alabalığı (Oncorhynchus mykiss) & [21] \\
\hline MAP & Gökkuşağı alabalığı (Oncorhynchus mykiss) & [22] \\
\hline MAP & Midye (Mytilus galloprovincialis) & [23] \\
\hline MAP & Gökkuşağı alabalığı (Oncorhynchus mykiss) & [24] \\
\hline MAP & Hamsi (Engraulis encrasicolus) & [25] \\
\hline MAP & Sarı yüzgeçli ton balığı (Thunnus albacares) & [26] \\
\hline MAP & Mezgit (Merlangius merlangus) & [27] \\
\hline MAP & Gökkuşağı alabalığı (Oncorhynchus mykiss) & [28] \\
\hline MAP & Çipura (Sparus aurata) & [29] \\
\hline MAP & Yunus (Coryphaena hippurus) & [30] \\
\hline MAP & Morina (Gadus morhua) & [31] \\
\hline MAP & Sazan (Cyprinus carpio) & [32] \\
\hline SV & $\begin{array}{l}\text { Gökkuşağı alabalığı (Oncorhynchus mykiss) ve } \\
\text { somon (Salmo Salar) }\end{array}$ & [33] \\
\hline SV & Gökkuşağı alabalığı (Oncorhynchus mykiss) & [34] \\
\hline SV & Çipura (Sparus aurata) & [35] \\
\hline SV & Somon (Salmo Salar) & [36] \\
\hline SV & Gökkuşağı alabalığı (Oncorhynchus mykiss) & [37] \\
\hline SV & Levrek (Micropterus haiaka) ve akya (Lichia amia) & [38] \\
\hline SV & Somon (Salmo Salar) & [39] \\
\hline SV & Gökkuşağı alabalığı (Oncorhynchus mykiss) & [40] \\
\hline SV & Istakoz (Homarus americanus) & [41] \\
\hline SV & Uskumru (Scomber scombrus) & [42] \\
\hline SV & Siyah levrek (Micropterus salmoides) & [43] \\
\hline SV & Arapayma (Arapaima gigas) & [44] \\
\hline SV & Morina (Gadus morhua) & [45] \\
\hline SV & Avrupa deniz levreği (Dicentrarchus labrax) & {$[46]$} \\
\hline
\end{tabular}

\section{Yenilikçi Paketleme Yöntemleri}

Gıda muhafazası konusunun gelişimi ile birlikte; ambalaj ürünü koruma görevinin dışında, tüketici açısından da önemli bir hal almıştır. Ambalaj materyali seçiminde tüketiciyi meraklandırma, cezbetme ve 
tüketiciye bilgi verme gibi faktörler önem kazanmıştır. Bunun bir sonucu olarak pasif ambalajlama yöntemleri günümüzde yerini aktif ve akıllı ambalajlama yöntemlerine bırakmıştır. Pasif ambalajlamada amaç sadece ürünü korumaktır. Aktif ve akıllı ambalajlama da ise ürünün korunmasının yanı sıra satılması, özelliklerinin iyileştirilmesi, çevresel atık değerlerinin azaltılması amaçlanmaktadır. Bunun bir sonucu olarak, biyoplastik materyal teknolojileri, yenilebilir filmler ve kaplamalar, MAP teknolojileri, aktif ve akıllı paketleme teknolojileri gibi yenilikçi gıda ambalajlama yöntemlerine yönelik bilimsel çalışmalar önem kazanmıştır [47].

Literatürde yenilikçi ambalajlama yöntemleri ile ilgili birçok terim bulunmaktadır. Ancak bu terimlerin tam anlamiyla tanımları yapılamamıştır. Bu nedenle 1999-2001 y1llarında Avrupa'da akıllı ve aktif ambalajlama yöntemlerinin; ekonomik ve çevresel etkileri, güvenilirliğinin değerlendirilmesi, tüketici beklentilerinin ve yararl1lıklarının tespitini kapsayan bir proje (ACTIPAK-FAIR CT984170) gerçekleştirilmiştir. Bu proje kapsamında aktif ve akıllı ambalajlama tanımı şu şekilde yer almıştır:

Aktif ambalajlama, ürünün mikrobiyolojik, kimyasal ve duyusal kalitesinin korunması ve böylece raf ömrünün artırılması amacıyla ambalajlı ürünün ortamının değiştirilmesidir.

Akıllı ambalajlama; ambalajlı gıdanın taşınması ve depolanması sırasında maruz kaldığı şartları göstererek ürün hakkında bilgi veren sistemlerdir.
Aktif ambalajlama sistemlerinden biri olan antimikrobiyel ambalajlama, gıdanın canlı mikroorganizma miktarını azaltıp gıda güvenliğini sağlayan yeni bir ambalajlama yöntemidir. Gıdaların besin değerini koruyarak raf ömrünü güvenli biçimde artırmayı sağlayan ambalaj malzemeleri geliştirilmesi konusunda araştırma ve geliştirme faaliyetleri devam etmektedir. Araştırma ve geliştirme çalışmalarında nanoteknolojiden de yararlanılmaktadır [47]. Bazı yenilikçi paketleme yöntemleri ile ilgili aşağıda detaylı bilgiler verilmiştir.

\section{Nanoteknoloji Tabanlı Paketleme Teknolojileri}

Nanoteknoloji, maddeler üzerinde 100 nanometre ölçeğinden küçük boyutlarda gerçekleştirilen işleme, ölçüm, tasarım, modelleme ve düzenleme gibi çalışmalarla maddeye atom ve molekül seviyesinde gelişmiş veya tamamen yeni fiziksel, kimyasal ve biyolojik özellikler kazandırmayı hedefleyen, yeni ve hızla gelişen bir bilim ve teknoloji alanıdır [48].

Gıda teknolojisinde, nanoteknojinin en fazla uygulandığı alan gıda ambalajlama olarak bilinmektedir. Özellikle gıdaların raf ömrü ve kalitesi açısından işlenmiş et ve su ürünleri ile taze meyve-sebzelerin ambalajlanmasinda nanoteknoloji uygulamalarını içeren çalışmalar devam etmektedir [49].

Nanoteknoloji,

- Ambalaj malzemesinin bariyer özelliklerini geliştirmek amacıyla, nanopartiküller $\left(\mathrm{SiO}_{2}\right.$, montmorillonit vb.) sentetik polimer 
ve/veya biyopolimer bazlı ambalaj malzemelerinin üretiminde kullanılarak, bariyer ve mekanik özellikleri daha iyi olan ambalajların geliştirilmesinde,

- Antimikrobiyal veya $\mathrm{O}_{2}$ absorbe etme gibi aktif özelliklere sahip nanoparçacıklar (Ag, $\mathrm{ZnO}, \mathrm{TiO}_{2} \mathrm{vb}$.) kullanılarak aktif ambalaj malzemelerinin geliştirilmesinde,

- Gıdanın maruz kaldığı depolama koşullarını, küçük organik molekülleri, gazları ve mikroorganizma bulaşımını gösteren belirteçlerin üretiminde farklı nanopartiküller $\quad\left(\begin{array}{llll}\mathrm{Fe}_{2} \mathrm{O}_{3}, & \mathrm{TiO}_{2} & \text { vb. })\end{array}\right.$ kullanılarak nanosensörlerin üretiminde,

- Ayrıca, akıllı ambalajların geliştirilmesinde kullanılabilmektedir $[14,47,50]$.

Nanoteknoloji tabanlı paketleme teknolojisi, raf ömrünü uzatmak için antimikrobiyalleri, antioksidanları, enzimleri, kokuyu ve nutrasötikleri serbest bırakmak için de uygulanabilir [51].

Gıda ambalajlamada, çevre dostu, gıdanın raf ömrünü arttıran, ürün kalitesi ve güvenliğini en iyi şekilde koruyan ambalaj malzemesi arayışı, nano-biyokompozit malzemelerin gelişmesini sağlamıştır. Nano-biyokompozitler; bitkisel veya hayvansal kaynaklı polisakkaritler, proteinler, lipidler gibi biyopolimer matrikslerin içerisine, dolgu malzemesi olarak nanopartikül ilave edilmesiyle elde edilmektedir. Biyopolimerlerin içerisine; kütlece \%1-5 katmanlı silikat nano-partiküller ilave edilerek nano-biyokompozit materyalin, biyobozunur olma özelliği korunurken ambalaj malzemesi olarak kullanımını sınırlandıran zayıf yönleri iyileştirilmektedir [52].
Nanoteknolojinin uygulandığı diğer bir uygulama olan nanosensörler, toksin üreten ya da gida zehirlenmesine yol açan mikroorganizmaları, sebep oldukları renk, kütle ve sıcaklık değişiklikleri ve moleküler tanıma sistemleri ile hızlı bir şekilde algılayabilmektedir. Örneğin; MAP yöntemi uygulanan, nano- $\mathrm{TiO}_{2}$ ve nano- $\mathrm{SnO}_{2}$ sensörleri yerleştirilen ambalajlarda mikrobiyal gelişme sonucu paketteki $\mathrm{O}_{2}$ konsantrasyonu arttığında bu nanoparçacıklar polimer ortamındaki redoks boyalarını ışığa duyarlı hale getirmekte ve paketteki sensör renginde ağarma görülmektedir [53-55]. Ambalajlar dışında nanotabanlı materyallerin direkt balıketine kaplandığı çalışmalar da günümüzde hızla artmaya başlamıştır.

\section{Akıllı Paketleme Teknolojileri}

American Heritage Dictionary'e göre akıllı sözcüğü, "Sağlam yargılama ve rasyonellik gösterme: ak1llı bir karar; soruna akıllıca bir çözüm” olarak tanımlanmaktadır. Akıllı paketleme (AP) ise, ürünün raf ömrünü uzatma, ürün kalitesini artırma ve ürünün bozulması ile ilgili bilgi sağlama olanaklarına sahip paketleme yöntemi olarak tanımlanmaktadır [56].

Tüketiciye gıdanın güvenliği ve kalitesi hakkında bilgi veren AP yönteminde; gıdada raf ömrü süresince hissetme, izleme ve işaret etme özellikleriyle ürünün içinde veya dışındaki değişimin görülebilmesi, başka bir ifadeyle ürün kalitesi ile iletişim kurulabilmesi söz konusudur [57]. 
AP yönteminde sensörler ve indikatörler kullanılmaktadır. Bu sensörler:

- Gaz sensörleri,

- Floresan esasli $\mathrm{O}_{2}$ sensörleri,

- Biyosensörler,

- Nanosensörler.

İndikatörler:

- Tazelik indikatörleri

- $\mathrm{pH}$ değişimine duyarlı tazelik indikatörleri,

- $\mathrm{N}_{2}$ gazına duyarlı tazelik indikatörleri,

- Hidrojen sülfüre $\left(\mathrm{H}_{2} \mathrm{~S}\right)$ duyarlı tazelik indikatörleri,

- Çeşitli metabolitlere duyarlı tazelik indikatörleri,

- Difüzyon bazlı indikatörler,

- Sizıntı indikatörleri,

- Patojen indikatörleri,

- Zaman ve sicakl1k indikatörleri,

- Kritik zaman ve sıcaklık indikatörleri,

- Enzimatik zaman ve sıcaklık indikatörleri,

- Polimer bazlı zaman ve sicaklık indikatörleri.

Bunların yanı sıra barkodlar (çizgi kod) ve radyo frekansı tanımlama etiketleri (RFID) de AP yönteminde kullanılan sistemlerdir [57-59]. AP yönteminde kullanılan sensörler, ürünün tazeliği, üründe mikrobiyal bozulma olup olmadığı, oksidatif acılaşma ve sıcaklığa bağlı değişmeler hakkında bilgi vermektedir. Sensörler ölçüm yapabilmek için gıdadan devamlı sinyal almalıdır. Sensörlerin büyük kısmı temel olarak reseptör ve çevirgeç birimlerinden oluşmaktadır. Reseptörler kaynak iletişimi ile alınan fiziksel ve kimyasal veriyi çevirgecin ölçebileceği enerjiye dönüştürürler.
Sensörler, elektriksel, optiksel, termal ve kimyasal olarak sinyalleri algılamaktadırlar [55].

Ambalajın içinde veya dişında bulunabilen indikatörler dış ortam şartları ve tepe boşluğu gazları sayesinde gıdanın kalitesi hakkında bilgi vermektedirler. Gıdanın ambalaj içinde muhafaza edildiği süre boyunca sıcaklık, mikrobiyal bozulma, ambalaj bütünlüğü, fiziksel şok, orjinallik gibi özelliklerinin korunması amaciyla çeşitli indikatörler kullanılmaktadır. Kullanılan indikatörlerin bir kısmı gıda ile reaksiyona girerken bir kısmı ise herhangi bir reaksiyona girmeden bilgi verebilmektedirler [60].

Barkod, farklı kalınlıktaki dik çizgi ve boşluklardan oluşan, verinin otomatik olarak ve hatasız bir şekilde farklı bir ortama aktarılması amacıyla kullanılan bir AP paketleme yöntemi belirtecidir. Ürünlerin tanımlanması nedeniyle 12 Avrupa Ülkesi k1lavuzluğunda standart bir sistem geliştirilmiş ve EAN (Avrupa Mal Sistemi) kurulmuştur. Tüketim birimleri için "EAN-8" (8 haneli) ve "EAN-13" (13 haneli) olmak üzere 2 barkod sistemi kullanılmaktadır [57].

RFID etiketler, radyo dalgaları kullanılarak etiket okuma ve ürünü uzaktan izleme olanağı sağlayan bir teknolojidir. Çalışma prensibi; mikroçipler ürünlere yerleştirilir, fiziksel etkileşim yerine, ürünlerin kimliklerinin radyo dalgalarıyla okunması sağlanır. Sistem; etiket, anten, okuyucu, sorgulayıcı ve denetleyici olmak üzere beş temel bileşenden oluşmaktadır. 
RFID etiketi; antene bağlı bir mikroçip ve antenli bir okuyucudan oluşmaktadır. Mikroçipler; disk, cam kapsül, etiket şeklinde olabilmektedir. Etiketlerin zaman-sıcaklık indikatörü veya bir sensör ile birleştirilebildiği belirtilmektedir. $\mathrm{Bu}$ teknoloji, mağaza içi güvenlik sistemlerinden stok takibine kadar birçok alanda kullanılmaktadır. Bir RFID okuyucusuyla büyük bir deponun ortasında durup cihaz çalıştırıldığında stokta nelerin olup olmadı $\breve{g} 1 \quad$ aynı anda ekranda görüntülenebilmektedir [61]

Tablo 2. Yenilikçi paketleme yöntemleri ile ilgili yapılan bazı çalışmalar

\begin{tabular}{lll}
\hline Paketleme Metodu & Uygulanan Su Ürünü & Literatür \\
\hline Nanoteknoloji Tabanlı & Levrek (Dicentrarchus labrax) & {$[62]$} \\
Nanoteknoloji Tabanlı & Gökkuşağı alabalığı (Oncorhynchus mykiss) & {$[63]$} \\
Nanoteknoloji Tabanlı & Gökkuşağı alabalığı (Oncorhynchus mykiss) & {$[64]$} \\
Nanoteknoloji Tabanlı & Gökkuşağı alabalığı (Oncorhynchus mykiss) & {$[65]$} \\
Nanoteknoloji Tabanlı & Gökkuşağı alabalığı (Oncorhynchus mykiss) & {$[66]$} \\
Nanoteknoloji Tabanlı & Gökkuşağı alabalığı (Oncorhynchus mykiss) & {$[67]$} \\
Nanoteknoloji Tabanlı & Gökkuşağı alabalığı (Oncorhynchus mykiss) & {$[68]$} \\
Nanoteknoloji Tabanlı & Uskumru (Scomber scombrus) & {$[69]$} \\
Nanoteknoloji Tabanlı & Gökkuşağı alabalığı (Oncorhynchus mykiss) & {$[70]$} \\
Nanoteknoloji Tabanlı & Gökkuşağı alabalığı (Oncorhynchus mykiss) & {$[71]$} \\
Nanoteknoloji Tabanlı & Karides (Macrobrachium rosenbergii) & {$[72]$} \\
Nanoteknoloji Tabanlı & Tilapia fillets & {$[73]$} \\
Nanoteknoloji Tabanlı & Restructured fish surimi & {$[74]$} \\
Nanoteknoloji Tabanlı & Morina (Gadus morhua) & {$[75]$} \\
\hline
\end{tabular}

\section{Sonuç}

Paketleme yöntemlerinin balıketi muhafazası ile ilgili yapılan çalışmalar göz önünde bulundurulduğunda paketlenmiş ürünün raf ömrü üzerine; ürün çeşidi, ambalaj türü, SV yöntemi için pişirme sıcaklığ 1 ve süresi, MAP yöntemi için kullanılan gaz çeşidi ve oranları, nanoteknoloji tabanlı paketleme yöntemi için kullanılan nanoparçacıklar ve tüm paketleme yöntemlerinde ürünün depolama sıcaklığı gibi birçok faktörün etkili olduğu sonucu çıkarılmaktadır. Genel olarak paketlenmiş ürünlerin, herhangi bir işlem uygulanmayan ürünlere göre daha uzun raf ömrüne sahip olduğu görülmektedir. Tüketime hazır gıdalara olan talebin artması da paketlemenin önemini artırmaktadır.

Sonuç olarak, su ürünlerinin besin değerinin korunarak raf ömrünün artırılması amaciyla uygun paketleme yönteminin seçilmesi için daha fazla çalışma yapılması hem üretici hem de tüketici açısından faydalı olacaktır. 
Teşekkür -

Fon/Finansman bilgileri Yazarlar bu çalışmanın araştırması, yazarlığı veya yayınlanması için herhangi bir mali destek almamışlardır.

\section{Etik Kurul Onayı ve İzinler -}

ISSN: 2536-4383

Çıkar çatışmaları/Çatışan çıkarlar Yazarlar

çıkar çatışması olmadığını beyan eder.

Yazarların Katkısı Tüm yazarlar, bu çalışmanın planlanmasına, yürütülmesine veya analizine yazar olarak dahil edilmek üzere yeterince katkıda bulunmuştur. Tüm yazarlar makalenin son halini okumuş ve onaylamıştır.

\section{Kaynaklar}

[1] Kaya, Y., Duyar, A. H., \& Erdem, M. E. (2004). Balık yağ asitlerinin insan sağlı̆̆ için önemi. Ege Üniversitesi Su Ürünleri Dergisi, 21(3-4), 365-370.

[2] Hisar, Ş. A., Hisar, O., \& Yanık, T. (2004). Balıklarda mikrobiyolojik, enzimatik ve kimyasal bozulmalar. Atatürk Üniversitesi Ziraat Fakültesi Dergisi, 35(3-4), 261-265.

[3] Ufuk, D., \& Sarımehmetoğlu B. (2016). Balık etinin muhafazasında soğutma ve dondurma yöntemleri. Erciyes Üniversitesi Veteriner Fakültesi Dergisi, 13(2), 151-158.

[4] Kaba, N., \& Duyar, A. H. (2008). Antimikrobiyal paketleme. Ege Üniversitesi Su Ürünleri Dergisi, 25(2), 181-185.

[5] Oğuzhan, P., \& Angiş, S. (2008, Mayıs 21-23). Su Ürünlerinin paketlenmesi. Türkiye 10. G1da Kongresi, Erzurum, Türkiye.

[6] Karakaya, E. (2013). Farklı şekillerde paketlenmiş salmo trutta macrostigma (Dumeril, 1858)'nın $4 \pm 1^{\circ} \mathrm{C}$ 'de raf ömrünün belirlenmesi. (Tez no. 334610) [Yüksek Lisans Tezi, Firat Üniversitesi].

[7] Göktan, D. (1990). Gldaların mikrobiyal ekolojisi. Ege Üniversitesi Basımevi, Mühendislik Fakültesi Yayınları.

[8] Ünlütürk, A., \& Turantaş, F. (1998). Glda mikrobiyolojisi. Sidas Medya Ltd. Şti.

[9] Kılınç, B., \& Çaklı, Ş. (2001). Paketleme tekniklerinin balık ve kabuklu su ürünleri mikrobiyal florası üzerine etkileri. Ege Üniversitesi Su Ürünleri Dergisi, 18(1-2), 279-291.

[10] Özoğul, Y., Özoğul, F., \& Küley, E. (2006). Modifiye edilmiş atmosfer paketlemenin balık ve balık ürünlerine etkisi. Ege Üniversitesi Su Ürünleri Dergisi, 23(1-2), 193-200.

[11] Gülyavuz, H., \& Ünlüsayın, M. (1999). Su ürünleri işleme teknolojisi. Hatiboğlu Yayıncılık.

[12] Gökoğlu, N. (2019). Innovations in seafood packaging technologies: a review. Food Reviews International, 36(4), 340-366. https://doi.org/10.1080/87559129.2019.1649689

[13] Smith, J. P., Ramaswamy, H. S., \& Simpson B. K. (1990). Developments in food packaging technology. Part II: Storage aspects. Trends in Food Science and Technology, 1, 111-118. https://doi.org/10.1016/0924-2244(90)90086-E

[14] Karagöz, Ş., \& Demirdöven, A. (2017). Gıda ambalajlamada güncel uygulamalar: modifiye atmosfer, aktif, akıllı ve nanoteknolojik ambalajlama uygulamaları. Gaziosmanpaşa Bilimsel Araştırma Dergisi, 6(1), 9-21.

[15] Schellekens, M. (1996). New research issues in sous-vide cooking. Trends in Food Science and Technology, 7(8), 256-262. https://doi.org/10.1016/0924-2244(96)10027-3 
[16] Baldwin, D. E. (2012). Sous vide cooking: a review. International Journal of Gastronomy and Food Science, 1, 15-30. https://doi.org/10.1016/j.ijgfs.2011.11.002

[17] Ceylan, Z., \& Şengör G. F. Ü. (2017). Sous vide teknolojisi ile muamele edilen balıkların kalite parametrelerinin incelenmesi. Turkish Journal of Aquatic Sciences, 32(1), 8-20. https://doi:10.18864/TJAS201702

[18] Leistner, L., \& Gorris, L. G. M. (1995). Food preservation by hurdle technology. Trends in Food Science Technology, 6, 41-45. https://doi.org/10.1016/S0924-2244(00)88941-4

[19] Özoğul, F., Polat, A., \& Özoğul, Y. (2004). The effects of modified atmosphere packaging and vacuum packaging on chemical, sensory and microbiological changes of sardines (Sardina pilchardus). Food Chemistry, 85, 49-57. https://doi.org/10.1016/j.foodchem.2003.05.006

[20] Erdem, M. E., Koral, S., \& Işıdan, S. (2017). Farklı paketleme yöntemlerinin tirsi (Alosa immaculata, Bennett, 1838) marinatlarındaki mikrobiyolojik ve biyojenik amin değişimlerine etkisi. Tarım Bilimleri Dergisi, 23(2017), 404-414.

[21] Hisar, Ş. A., Hisar, O., Kaya, M., \& Yanık T. (2004). Effects of modified atmosphere and vacuum packaging on microbiological and chemical properties of rainbow trout (Oncorhynchus mykiss) fillets. $\begin{array}{llll}\text { International Journal of Food } & \text { Microbiology, } 214 .\end{array}$ https://doi.org/10.1016/j.ijfoodmicro.2004.05.024

[22] Çaklı, Ş., Kılınç, B., Dinçer, T., \& Tolasa, S. (2006). Comparison of the shelf lifes of map and vacuum packaged hot smoked rainbow trout (Onchorynchus mykiss). European Food Research and Technology, 224, 19-26. https://doi.org/10.1007/s00217-006-0283-3

[23] Turan, H., \& Onay, R. T. (2015). Modifiye atmosfer paketleme uygulanan midyelerin (Mytilus galloprovincialis, Lamarck 1819) buzdolab1 $\left(4 \pm 2^{\circ} \mathrm{C}\right)$ koşullarında raf ömrünün tespiti. Journal of Food and Health Science, 1(4), 185-198. https://doi.org/10.3153/JFHS15018

[24] Oğuzhan, P., \& Angiş, S. (2012). Effect of salting and packaging treatments on fresh rainbow trout (Oncorhynchus mykiss) fillets during storage at refrigerator temperatures. Kafkas Üniversitesi Veteriner Fakültesi Dergisi, 18, 443-448.

[25] Keskin, İ. (2019). Farklı paketleme tekniklerinin hamsi (Engraulis encrasicolus L., 1758) marinatı üzerine uygulanabilirliği ve kalitelerinin incelenmesi (Tez no. 575477). [Doktora tezi, Sinop Üniversitesi].

[26] Silbande, A., Adenet, S., Smith-Ravin, J., Joffraud, J. J., Rochefort, K., \& Leroi, F. (2016). Quality assessment of ice stored tropical yellowfin tuna (Thunnus albacares) and influence of vacuum and modified atmosphere packaging. Food Microbiology, 60(2016), 62-72. https://doi:10.1016/j.fm.2016.06.016: 62-72

[27] Hassoun, A., \& Karoui, R. (2016). Monitoring changes in whiting (Merlangius merlangus) fillets stored under modified atmosphere packaging by front face fluorescence spectroscopy and instrumental techniques. Food Chemistry, 200, 343-353. https://doi:10.1016/j.foodchem.2016.01.028:343-353

[28] Rodrigues, B. L., Da Silveira Alvares, T., Sampaio, G. S. L., Cobral, C. C., Araujo, J. V. A., Franco, R. M., Mano, S. B., \& Juior, C. A. C. (2016). Influence of vacuum and modified atmosphere packaging in combination with UV-C radiation on the shelf life of rainbow trout (Oncorhynchus mykiss) fillets. Food Control, 60, 586-605. https://doi.org/10.1016/j.foodcont.2015.09.004 
[29] Parlapani, F. F., Kormas, K. A., \& Boziaris, I. S. (2015). Microbiological changes, shelf life and identification of initial and spoilage microbiota of sea bream fillets stored under various conditions using 16S rRNA gene analysis. Journal of the Science Food Agriculture, 95(12), 2386-2394. https://doi:10.1002/jsfa.6957

[30] Messina, C. M., Bono, G., Renda, G., La Barbera, L., \& Santulli, A. (2015). Effect of natural antioxidants and modified atmosphere packaging in preventing lipid oxidation and increasing the shelflife of common dolphinfish (Coryphaena hippurus) fillets. LWT-Food Science and Technology, 62, 271277. https://doi.org/10.1016/j.lwt.2015.01.029

[31] Hansen, A.A., Moena, B., Rodbottena, M., Bergeta, I., \& Pettersen, M.K. (2016). Effect of vacuum or modified atmosphere packaging (MAP) in combination with a $\mathrm{CO}_{2}$ emitter on quality parameters of cod loins (Gadus morhua). Food Packaging and Shelf Life, 9, 29-37. https://doi.org/10.1016/j.fpsl.2016.05.005

[32] Babic, J., Milijasevic, M., Vranic, D., Veskovic-Moracanin, S., \& Djinovic-Stojanovic, J. (2015). Effect of modified atmosphere packaging on the shelf-life of common carp (Cyprinus carpio) steaks. Procedia Food Science, 5, 2-5. https://doi:10.1016/j.profoo.2015.09.084

[33] Garcia-Linares, M.C., Gonzalez-Fandos, E., Garcia-Arias, M.T., \& Garcia-Fernandez, M.C., (2004). Microbiological and nutritional quality of sous vide or traditionally processed fish: Influence of fat content. Journal of Food Quality, 27(5), 371-387. https://doi.org/10.1111/j.1745-4557.2004.00676.x

[34] Gonzalez-Fandos, E., Garcia-Linares, M.C., Villarino-Rodriguez, A., Garcia-Arias, M.T., \& Garcia- Fernandez, M.C. (2004). Evaluation of the microbiological safety and sensory quality of rainbow trout (Oncorhynchus mykiss) processed by the sous vide method. Food Microbiology, 21, 193201. https://doi.org/10.1016/S0740-0020(03)00053-4

[35] Andres-Bello, A., Garcia-Segovia, P. \& Martinez-Monzo, J. (2009). Effects of vacuum cooking (Cook-Vide) on the physical-chemical properties of sea bream fillets (Sparus aurata). Journal of Aquatic Food Product Technology, 18(1-2), 79-89. https://doi.org/10.1080/10498850802581773

[36] Diaz, P., Garrido, M. D., \& Banon, S. (2011). Spoilage of sous vide cooked salmon (Salmo salar) stored under refrigeration. Food Science and Technology International, 17(1), 31-37. https://doi: $10.1177 / 1082013210368744$

[37] Çetinkaya, S., Bilgin, Ş., Ertan, Ö. O., \& Bilgin, F. (2015). Vakum paketli pişirme yöntemi (Sous Vide) ve gökkuşağı alabalığı (Oncorchynchus mykiss, Walbaum 1792)'na uygulanması. Eğirdir Su Ürünleri Fakültesi Dergisi, 11(2), 35-44.

[38] Ceylan, Z., Şengör G.F.Ü., \& Gönülal O. (2015, March 23-24). The Effects of sous vide technology combined with different herbals on sensorial on physical quality of fish species caught in The Northern Aegean Sea and Marmara Sea, ICFAEST 2015: 17th International Conference on Fisheries, Aquaculture Economics and Seafood Trade, Prag, Chezch Republic.

[39] Şengör, G. F. Ü., Ceylan, Z., \& Alkan, T. (2015, Eylül 1-4). Farklı baharatlarla işleme alınan ve sous vide tekniği ile pişirilen somon balığı'nın (Salmo Salar) raf ömrünün belirlenmesi, 18. Ulusal Su Ürünleri Sempozyumu, İzmir, Türkiye.

[40] Çetinkaya, S. (2020). The effects of sous-vide cooking method on rainbow trout by adding natural antioxidant effective sage: basic quality criteria. Natural and Engineering Sciences, 5, 167-183. https://doi.org/10.28978/nesciences.832987 
[41] Humaid, S., Nayyar, D., Bolton, J., Perkins, B., \& Skonberg D. I. (2020). Refrigerated shelf-life evaluation of high pressure processed, raw and sous vide cooked lobster. High Pressure Research, 40(3), 444-463. https://doi: 10.1080/08957959.2020.1774753

[42] Cropotova, J., Mozuraityte, R., Standal, I. B., \& Rustad, T. (2019). The influence of cooking parameters and chilled storage time on quality of sous-vide atlantic mackerel (Scomber scombrus). Journal of Aquatic Food Product Technology, 28(5), 505-518. https://doi:10.1080/10498850.2019.1604595

[43] Wan, J., Cao, A., \& Cai, L. (2019). Effects of vacuum or sous-vide cooking methods on the quality of largemouth bass (Micropterus salmoides). International Journal of Gastronomy and Food Science, 18, 1-9. https://doi: 10.1016/j.ijgfs.2019.100181

[44] Hernandez, E. P., Almeida da Costa W., Furtado Araujo, E. A., Villa, P. M., Henriques Lourenço, L. F., \& Carvalho Junior, R. (2020). Influence of grilling pretreatment and optimization of sous vide processing parameters on the physicochemical and microbiological quality of pirarucu fillet. Food Science and Technology International, 27(1), 84-96. https://doi: 10.1177/1082013220934257

[45] Hassoun, A., Cropotova J., Rustad T., Heia, K., Lindberg S. K., \& Nilsen, H. (2020). Use of spectroscopic techniques for a rapid and non-destructive monitoring of thermal treatments and storage time of sous-vide cooked cod fillets. Sensors, 20(8), 2-17. https://doi:10.3390/s20082410

[46] Bolat, Y., Genç İ. Y., Tunca Y., \& Demirayak, M. (2018). Effect of laurel (Laurus nobilis) and curcuma (Curcuma longa) on microbiological, chemical and sensory changes in vacuum packed sousvide european sea bass (Dicentrarchus labrax) under chilled conditions. Food Science and Technology, 39, 159-165. https://doi:10.1590/fst.41217

[47] Polat, S., \& Fenercioğlu., H. (2014). Gıda ambalajlamasında nanoteknoloji uygulamaları: inorganik nanopartiküllerin kullanım1. Glda Dergisi, 39(3), 187-194. https://doi:10.5505/gida

[48] Tarhan, Ö., Gökmen, V., \& Harsa, Ş. (2010). Nanoteknolojinin gıda bilim ve teknolojisi alanındaki uygulamalar1. Gida Dergisi, 35(3), 219-225.

[49] Sürengil, G., \& Kılınç, B. (2011). Gıda ambalaj sektöründe nanoteknolojik uygulamalar ve su ürünleri açısından önemi. Journal of Fisheries Sciences, 5(4), 317-325. https://doi:10.3153/jfscom.2011036

[50] Duncan, T. V. (2011). Applications of nanotechnology in food packaging and food safety: barrier materials, antimicrobials and sensors. Journal of Colloid and Interface Science, 363(1), 1-24. https://doi.org/10.1016/j.jcis.2011.07.017

[51] Cha, D. S., \& Chinnan, M. S. (2004). Biopolymer-based antimicrobial packaging: a review. Critical Reviews in Food Science and Nutrition, 44, 223-237. https://doi:10.1080/10408690490464276

[52] Boyacıoğlu, D. (2015). G1da ambalajlamada nanoteknoloji uygulamaları. http://dilekboyacioglu.com/Gida_Ambalajlamada_Nanoteknoloji.pdf

[53] Azeredo, H. M. C. (2009). Nanocomposites for food packaging applications. Food Research International, 42(9), 1240-1253. https://doi.org/10.1016/j.foodres.2009.03.019

[54] Mills, A., \& Hazafy, D. (2009). Nanocrystalline Sno2-Based, UVB-activated, colourimetric oxygen indicator. Sensor and Actuators B: Chemical, 136, 344-349. https://doi.org/10.1016/j.snb.2008.12.048

[55] Y1lmazer, M., \& Altay, F. (2014). Gıda ambalajlarında nanoteknolojik uygulamalar ve faz değişim materyalleri. Glda Dergisi, 39(6), 371-378. https://doi:10.15237/gida.GD14024 
[56] Yam, K. L., Takhistov, P. T., \& Miltz, J. (2005). Intelligent packaging: concepts and applications. Journal of Food Science, 70(1), 1-10. https://doi.org/10.1111/j.1365-2621.2005.tb09052.x

[57] Öksüztepe, G., \& Beyazgül, P. (2014). Akıllı ambalajlama sistemleri ve gıda güvenliği. Firat Üniversitesi Sağllk Bilimleri Veteriner Dergisi, 29(1), 67-74.

[58] Gök, V. (2007). Gıda paketleme sanayinde akıllı paketleme teknolojisi. Grda Teknolojileri Elektronik Dergisi, 2007(1), 45-58.

[59] Hecer, C. (2012). Et teknolojisinde ambalajlama yöntemleri. Uludă̆ Üniversitesi Veteriner Fakültesi Dergisi, 31(1), 57-61.

[60] Hepsağ, F., \& Varol, T. (2018). Intelligent packaging use in food industry and traceability. Adyütayam, 6(1), 29-39.

[61] Üçüncü, M. (2011). Glda ambalajlama teknolojisi. Ambalaj Sanayicileri Derneği.

[62] Ceylan, Z., Şengör, G. F. Ü., \& Yılmaz, M. T. (2018). Nanoencapsulation of liquid smoke/thymol combination in chitosan nanofibers to delay microbioligical spoliage of sea bass (Dicentrarchus labrax) fillets. Journal of Food Engineering, 229, 43-49. https://doi.org/10.1016/j.jfoodeng.2017.11.038

[63] Ceylan, Z., Meral, R., Karakaş, C. Y., Dertli, E., \& Y1lmaz, M. T. (2018). A novel strategy for probiotic bacteria: ensuring microbial stability of fish fillets using characterrized probiotic bacterialoaded nanofibers. Innovative Food Science and Emerging Technologies, 48, 212-218. https://doi.org/10.1016/j.ifset.2018.07.002

[64] Ceylan, Z., Meral, R., Cavidoğlu, İ., Karakaş C. Y., \& Yılmaz, M. T. (2018). A new application on fatty acid stability of fish fillets: coating with probiotic bacteria-loaded polymer-based characterized nanofibers. Journal of Food Safety, 38(6), 1-9. https://doi:10.1111/jfs.12547:1-9

[65] Meral, R., Alav, A., Karakaş, C. Y., Dertli, E., Yılmaz, M. T., \& Ceylan, Z. (2019). Effect of electrospun nisin and curcumin loaded nanomats on the microbial quality, hardness and sensory characteristics of rainbow trout fillet. Food Science and Technology, 113, 1-8. https://doi:10.1016/j.lwt.108292:1-8

[66] Meral, R., Ceylan, Z., \& Köse, Ş. (2019). Limitation of microbial spoilage of rainbow trout fillets using characterized thyme oil antibacterial nanoemulsions. Journal of Food Safety, 39(4), 1-7. https://doi:10.1111/ifs.12644:1-7

[67] Ceylan, Z. (2019). A new cost-effective process for limitation of microbial growth in fish fleshes: Wrapping by aluminum foil coated with electrospun nanofibers. Journal of Food Safety, 39(5), 1-8. https://doi:10.1111/jfs.12697:1-8

[68] Durmuş, M., Özoğul, Y., Köşker A. R., Uçar, Y., Boğa, E. K., Ceylan, Z., \& Özoğul, F. (2019). The function of nanoemulsion on preservation of rainbow trout fillet. Journal of Food Science and Technology, 57(3), 895-904. https://doi.org/10.1007/s13197-019-04122-9

[69] Ekin, M. M., Alav, A., Meral, R., \& Ceylan, Z. (2019, Aralık 20-22). Nar çekirdeği yağı nanoemülsiyonu ile hazırlanmış yenilebilir hidrojel filmlerin balı filetolarının mikrobiyal yükü üzerine etkisi. Ispec 3. Uluslararası Tarım, Hayvancılık ve Kırsal Kalkınma Kongresi, Van, Türkiye.

[70] Özoğul, Y., Yuvka, I., Uçar, Y., Durmuş, M., Kösker, A. R., Öz, M., \& Özoğul, F. (2017). Evaluation of effects of nanoemulsion based on herb essential oils (rosemary, laurel, thyme and sage) on sensory, chemical and microbiological quality of rainbow trout (Oncorhynchus mykiss) fillets during ice storage. LWT-Food Science and Technology, 75, 677-684. https://doi.org/10.1016/j.lwt.2016.10.009 
[71] Hashemabad, Z. N., Shabanpour, B., Azizi, H., Ojagh, M.S., \& Alishahi, A. (2018). Effects of TiO2 nanocomposite packaging and gamma irradiation on the shelf-life of rainbow trout stored at $\left(+4{ }^{\circ} \mathrm{C}\right)$. Turkish Journal of Fisheries and Aquatic Sciences, 18, 1387-1397. https://doi: 10.4194/1303-2712v18_12_07

[72] Tang, Z. P., Chen C. W., \& Xie, J. (2018). Development of antimicrobial active films based on poly(vinyl alcohol) containing nano-TiO2 and its application in macrobrachium rosenbergii packaging. Journal of Food Processing and Preservation, 42(8), 1-12. https://doi.org/10.1111/jfpp.13702

[73] Winayu, I. J., Ekantari, N., PuspitaI, D., Budhijanto, W., \& Nugraheni, P. S. (2019). The effect of reduced acetic acid concentration on nano-chitosan formulation as fish preservative. IOP Conference Series: Materials Science and Engineering, 633, 1-6. https://doi:10.1088/1757-899X/633/1/012040

[74] Hajji, S., Hamdi, M., Boufi, S., Li, S., \& Nasri, M. (2019). Suitability of chitosan nanoparticles as cryoprotectant on shelf life of restructured fish surimi during chilled storage. Cellulose, 26, 6825-6847. https://doi.org/10.1007/s10570-019-02555-1

[75] Mizielinska, M., Kowalska, U., Jarosz, M., \& Suminska, P. (2018). A comparison of the effects of packaging containing nano $\mathrm{ZnO}$ or polylysineon the microbial purity and texture of cod (Gadus morhua) fillets. Nanomaterials, 8(3), 158-171. https://doi.org/10.3390/nano8030158 